\title{
Small business networks in the field of organic farming: strategies and management tools
}

\section{Redes de pequenas empresas no contexto da agricultura orgânica: estratégias e instrumentos para a gestão}

\author{
Jaqueline de Fátima Cardoso ${ }^{1}$, Nelson Casarotto Filho ${ }^{2}\left(\mathbb{D}\right.$, Christian Marcon $^{3}$ \\ ${ }^{1}$ Instituto Federal de Educação, Ciência e Tecnologia de Santa Catarina - IFSC, Campus Florianópolis-Continente, \\ Florianópolis, SC, Brasil. E-mail: jaque@ifsc.edu.br \\ ${ }^{2}$ Universidade Federal de Santa Catarina - UFSC, Programa de Pós-Graduação em Engenharia de Produção, \\ Florianópolis, SC, Brasil. E-mail: nelson.casarotto@ufsc.br \\ ${ }^{3}$ Université de Poitiers, Institut d'Administration des Entreprises, Poitiers, France. \\ E-mail: christian.marcon@univ-poitiers.fr
}

How to cite: Cardoso, J. F., Casarotto Filho, N., \& Marcon, C. (2020). Small business networks in the field of organic farming: strategies and management tools. Gestão \& Produção, 27(4), e4730.

https://doi.org/10.1590/0104-530X4730-20

\begin{abstract}
Business cooperation networks are based on specific parameters: common goal, competitive earnings, interaction among partners and management. Networks of farmers focused on organic production are growing due to the increasing demand. The objective of this research is to propose a framework of organizational strategies and management and governance tools for networks of small businesses operating in the field of organic farming. The methodology adopts a qualitative approach and it is comprised by a conceptual and theoretical review as well as two case studies. The proposed framework shows organizational strategies and management tools- that are crucial for the networks to thrive. Management instruments include, strategic, integration, contractual and decision-making instruments. Global strategies correspond to strategies regarding competitiveness, strategies regarding the product/market and strategies regarding the use of means. The value chain activities comprise the functional strategies. Results revealed significant particularities and common aspects of the organizational strategies and management tools.
\end{abstract}

Keywords: Small business networks; Cooperation networks; Network management; Organic farming.

Resumo: A formação de redes de cooperação empresarial fundamenta-se nos seguintes elementos: objetivos comuns, ganhos competitivos, interação e gestão. As redes de produtores de orgânicos vêm aumentando a atividade devido ao crescimento da procura por alimentos orgânicos. Propor um esquema teórico-conceitual, orientado para estratégias organizacionais e instrumentos para a gestão de redes horizontais de pequenas empresas no contexto da agricultura orgânica, é o objetivo geral deste trabalho. Um estudo teórico-conceitual e dois estudos de casos, com abordagem qualitativa constituem os procedimentos metodológicos. O esquema teórico-conceitual proposto considera instrumentos de gestão e estratégias organizacionais, elementos relevantes para gerir e preservar a sobrevivência das redes. Instrumentos para a gestão compreendem instrumentos estratégicos, de integração, contratuais e de tomada de decisão. As estratégias globais correspondem às estratégias quanto à

Received Mar. 26, 2018 - Accepted July 21, 2018

Financial support: Coordenação de Aperfeiçoamento de Pessoal de Nível Superior - Capes.

This is an Open Access article distributed under the terms of the Creative Commons Attribution License, which permits unrestricted use, distribution, and reproduction in any medium, provided the original work is properly cited. 
competitividade, quanto ao produto/mercado e quanto à utilização dos meios. As atividades da cadeia de valores compreendem as estratégias funcionais. Os resultados apontam particularidades significativas e pontos comuns dos instrumentos de gestão e das estratégias organizacionais.

Palavras-chave: Redes de pequenas empresas; Redes de cooperação; Gestão de redes; Agricultura orgânica.

\section{Introduction}

The establishment of a business cooperation network, according to Balestrin \& Verschoore (2008) is based on the following elements: common goals, competitive earnings, interaction between the participants and management. The specifics of such networks pose limits on the application of management models currently used in traditional businesses. Such features entail new organizational and management practices. The authors argue that issues such as collective strategy, mechanisms for commercial and production integration, innovation, and connection between structure and strategy, are issues to be researched further in the field of strategy in cooperation networks. According to the authors, networks alone are not sufficient to guarantee competitive earnings, which are accomplished when networks are managed based on new models. "The theories of organization and administration still do not present solutions that can be compatible with the challenges of the management of the networks" (Balestrin \& Verschoore 2008, p. 190). In addition to the lack of theories suggested by Balestrin \& Verschoore, Roth et al. (2012) point out that studies using networks as objects of analysis are rare, notwithstanding this kind of study would provide directions on how to reach success through cooperation.

In addition, regarding the development of theories for inter-organizational networks, Raab \& Kenis (2009) argue that organizational theory needs to advance on the comprehension of networks as objects of analysis. The authors suggest that there are few studies using networks as dependent variables and that look at explaining inter-organizational networks operation, structure, development, rules and governance.

Roth et al. (2012) point out that the Academy focused studies primarily on the motivation to establishing inter-organizational networks or on the benefits businesses can achieve through them. However, there are few studies on how these networks can be organized and coordinated in order to produce better results. The authors argue that the inter-organizational network creation, development and success are connected to the establishment of a governance and management system.

Andrighi et al. (2011) show that the research on business networks in Brazil followed an approach where the cooperation was considered in a geographical context that facilitates the inter-organizational relationships, such as clusters or agglomerations. Internationally, business cooperation can be understood as more structured relationships, where issues such as the network's governance are studied as a new organization. Thus, regarding conceptual aspects, the research in Brazil is based more strongly on the industrial economy, and lacks further studies with the aim of analyzing aspects of network management and elements related to the limits of this model regarding organizations competitiveness.

Such gaps in research can be observed in networks in the field of agriculture. Mount (2012) notes that the basis of governance of local food systems is: reconnection between farmers and consumers; direct exchange whereby reconnection appears; and shared goals and values. In this case, the management of such systems was disregarded. According to the author, these statements are based on tenuous assumptions about how interactions within the direct exchange produce value, and how local food systems are governed. 
The farmers networks focused on organic farming are increasing their activity, due to the growing demand for organic food all over the world, pushed by the awareness of the population regarding the risks related to chemical residues in food (Arbos et al., 2010). Maxey (2006), Trauger (2009) and Louden \& Macrae (2010) also point out the growing demand for organic food, and Demiryurek (2010) argues that increasing consumer demand for organic food has led to the development of these products international trade. Zanoli et al. (2012) add that the demand for organic food in the European Union and North America, the two main markets for organic food, has nearly doubled in the last decade. Retamales (2011) shows that, regarding fresh fruit intake, organic products had the highest increase (about 50\%) between 2002 and 2006. Lobley et al. (2009) argue that organic agriculture has experienced notable growth in recent years. However, the authors note that the focus of the debate is far from simplistic notions. Its focus is the local supply providing benefits to local economy. The debate develops toward a broader concept of local agrifood economy, in which some farmers have strong local connections, while others focus their efforts elsewhere, obtaining important export income for the local economy. According to data from the International Federation of Organic Agriculture Movements (IFOAM, 2017), the global market is growing and consumer demand is increasing. In 2000 the organic market was 17.9 billion dollars, while in 2016 the market was 89.7 billion dollars. Likewise, there was an increase in the number of producers that in 1999 was around 200,000 , and in 2016 reached the mark of 2.7 million producers.

Roth et al. (2012) say that the management of inter-organizational networks is performed through a governance and management system. The governance is responsible for the rules regarding the network's operation, the maintenance of the autonomy and the limits for the administration. Management is responsible for planning and implementing strategies, organization of activities, direction, control, etc. Both functions complement each other, but also present aspects in common.

Defining goals and working to reach them is an activity of the network management and organizational strategies are paths used to achieve these goals (Mintzberg, 2001). Among many possible categories, strategies can be classified as "global" or "operational". Global strategies are related to the entire organization and are connected to strategic objectives. Operational strategies focus on specific areas such as marketing, production, finance, human resources, and others operational areas (Casarotto, 2016; Porter 1991; Aaker, 2001).

The study in question was constructed based on the following assumption: Small companies alone have a lower chance of survival, so, participating in a network is a strategy adopted (Casarotto \& Pires, 2001). When networking, such companies explicitly or implicitly form an organization that would best develop if properly managed. Ricciardi (2012, p. 185) states that "[...] in Italian districts, the legal form of companies is more complex and the average size is higher than the companies outside the industrial district". Data from the 2011 report of the Osservatorio Nazionale Distretti Italiani show that microenterprises between one and nine employees represented $86 \%$ in the industrial districts, against $95 \%$ in the national average, while the companies with 10 to 249 employees accounted for $14 \%$, against $5 \%$ of the national average, which indicates greater chances of growth because they are integrated into districts industries.

In order to contribute to the system of governance and management of inter-organizational small businesses networks in the field of organic farming by proposing a framework, it was observed the need to create a model or theoretical contribution. According to Fleury (2012) a theoretical contribution is made from the understanding and use of previously published models and concepts about the field of study, in order to answer the research question. Therefore, it is necessary to understand these other models to deal with the phenomenon in which one is interested, and from these models, propose advances in the field of study. 
The framework for the governance and management system for inter-organizational networks of small businesses in the field of organic farming, which is the object of this study, consists of a set of organizational strategies - including global and operational strategies, as well as management tools - suitable for implementation in this type of network. In order to design this framework, the authors carried out a theoretical-conceptual study based on scientific articles produced in the field, as well as using two case studies. One case study was conducted in Brazil with the Ecovida Agro-ecology Network - in a section of the network based on the coast of Santa Catarina (called Núcleo Litoral Catarinense). The other case study was conducted in France, with the Groupement Régional Agricole Biologique - Agrobio Poitou-Charentes.

Figure 1 presents the proposal of this study. Management tools and organizational strategies used were identified based on the study of flexible networks in the field of organic farming, involving small farmers. These elements contributed to the development of a framework for network governance and management system (Roth et al., 2012). This framework contributes to the element 'management', which in addition to the elements 'competitive gains', 'interactions' and 'common goals', make up the elements for establishing cooperation networks proposed by Balestrin \& Verschoore (2008). Therefore, the purpose is to contribute to the element 'governance' and 'management' by proposing a framework built from management tools and organizational strategies. The parts of the scheme marked in gray represent such a contribution. The results of this study provide knowledge that can be used by small business networks' managers working with organic farming in order to increase the performance of the organization, as well as new networks that wish to establish within this context.

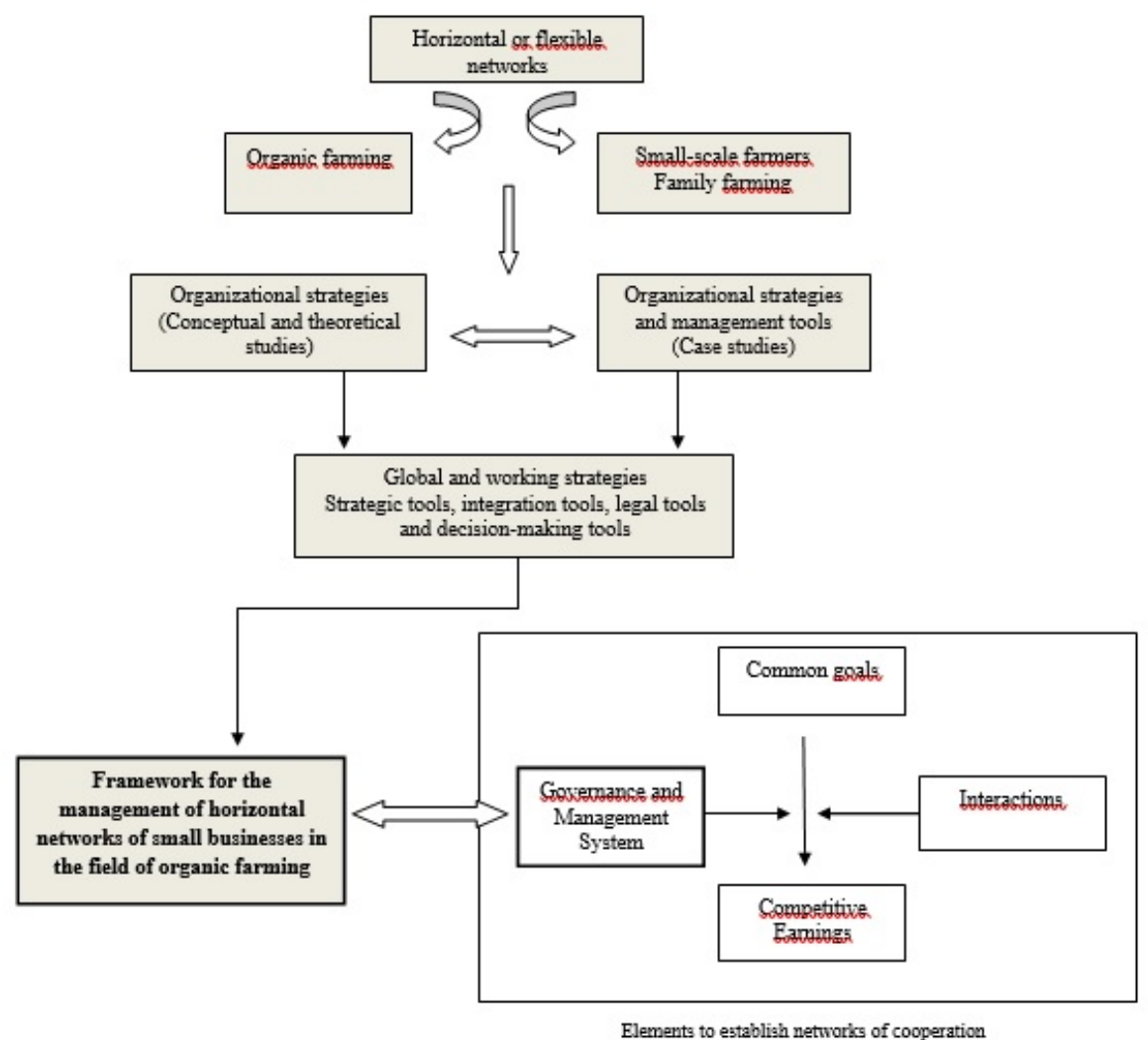

Figure 1. Proposal and contributions of the study.Source: Elaborated by the authors based on Balestrin \& Verschoore (2008, p. 152) and Roth et al. (2012, p. 120). 
Considering the above, the objective of this study is to propose a framework of organizational strategies and management tools for horizontal small business networks in the field of organic farming.

In the next section, the work presents theoretical review on business networks, governance and management, as well as the organizational strategies designed. Then the research methods will be presented, followed by the results and the conclusion.

\section{Business networks, governance and management}

The term companies networks has different denominations in the literature. For Casarotto \& Pires (2001), business networks are a set of companies interconnected by formal or business relationships, and may or may not be circumscribed to a region. Business cooperation networks, so called by Balestrin \& Verschoore (2008), are defined as organizations composed of a group of formally related companies, with common objectives, with unlimited existence, with multiple scope of action and with a formal structure of their own. In them, each member maintains the legal individuality, participates directly in the decisions, and symmetrically shares with the others the benefits and gains achieved by the collective efforts (Balestrin \& Verschoore, 2008).

According to Albers (2010) and Wegner \& Padula (2011) as the network grows in number of participants, the greater the likelihood of differences of opinion on specific issues such as goals or strategies. This brings the need for a higher level of centralization in decision-making and formalization of activities for the collective objectives to be achieved. In this case, formalization can mitigate this problem by default responses to various situations, reducing the chances of multiple interpretations and decreasing the potential for tension between the participants. The studies of Marcon \& Moinet (2001) also contribute in this direction.

For Lastres \& Cassiolato (2003), network governance is characterized by the existence of clusters of micro, small and medium-sized businesses, without large companies that are locally based exercising the role of coordination of economic and technological activities. They are marked by intensive relationships between a large number of agents where none of these agents is dominant. This definition is shared by Sacomano \& Paulillo (2012), among the types of governance highlighted by the authors. The type of structure that all groups do not have, is characterized by the absence of a leading company. There is no hierarchy, considering that the productive system has no differences and leadership among the actors.

Roth et al. (2012) conducted a study whose focus was to discuss the concepts of governance and management of inter-organizational networks. Both form the governance and management system of this type of network. These are distinct concepts, but interrelated and fundamental to the organization of inter-organizational networks. The authors explain that:

Governance is responsible for the definition of the network structure, the details of its organization, the adoption of regulatory mechanisms and the decision-making process. Management is responsible for planning, implementing and controling the strategies and actions, within the limits established by governance (Roth et al., 2012, p. 120). 
Therefore, within the limits imposed by the governance of the inter-organizational network, managers are free to use their knowledge and skills in order to plan and execute strategies to achieve the established goals (Roth et al., 2012).

As a result of observation of best management practices in cooperation networks and of management elements in the literature, Balestrin \& Verschoore (2008) present instruments to manage cooperation networks that are composed of strategic tools, integration tools, legal tools and decision-making tools.

Strategic tools are related to strategies that must be planned in a participatory way and goals that must also be defined in participatory processes. General guidelines are defined in the strategic planning. Elements needed in the action plan are determined in the operational implementation, and in order to implement the action plan, teams of strategic implementation are formed.

Integration tools play an important role in order to replace the hierarchical systems and align values, visions and practices, and enable companies to combine their individual interests with the collective interests. Examples of integration tools include organizing events between employees and the companies participating in the cooperation network; the promotion of meetings between business associates, and between entrepreneurs and their families with the network as a whole; and the network interaction with its surroundings.

Legal tools specify the rights and duties of those involved, organize existing resources, regulate the relationships between the participants and reduce conflicts and the likelihood of opportunistic actions. Examples of these tools are bylaws, internal regulations and code of ethics.

Decision-making tools support the open participation of the members, encouraging decentralization and members' engagement. For general decisions, deliberations in assemblies are a preferred tool. As for operational decisions, these should preferably take place at an operational level, including only those involved in the problem.

Among the business networks are those focused on agriculture, and in this type of organizational configuration, organic farming has been increasing (Arbos et al., 2010; Maxey, 2006; Trauger, 2009; Louden \& Macrae, 2010; Retamales, 2011; Lobley et al., 2009).

Being in a network is a strategy adopted by small companies in the context of organic agriculture (Casarotto \& Pires, 2001). In opting for this generic strategy, specific strategies are needed for this type of organization. The proposed theoretical-conceptual scheme has moved in this direction.

\section{Organizacional strategies}

Mintzberg (2001) conceptualizes organizational strategy as the path that leads the organization to achieve its goals. Strategy may be a plan for the future; a pattern based on the past performance of the organization; a position that locates certain products in specific markets; a perspective lead to adopt an ingrained way of doing things; and finally the strategy can be a trick, a specific maneuver to beat the competition. This definition indicates that the strategy includes the different ways used by organizations to achieve their goals.

Casarotto (2016) divides the organizational strategies into two groups: global strategies, which involve the organization as a whole, and operational strategies that correspond to specific operations of the business, such as production, marketing, human resources, finances, for example. In this work, operational strategies will be 
analyzed from the value chain. The authors, based on Porter (1991) and Aaker (2001), categorize the global strategies that compose the strategic mix into 03 strategies: (1) strategies for competitiveness; (2) strategies for product/market; and (3) strategies for using resources.

On strategies for competitiveness in the case of small businesses, it is possible to compete with the following strategies: product differentiation, associated or not to a market niche; cost leadership, in which the business participates as a supplier of a large top-down network; and differentiation/flexibility and cost leadership, in which the business participates in flexible business networks (Casarotto, 2016).

According to this point of view, Kim \& Mauborgne (2005) agree that businesses can opt for differentiation and cost leadership at the same time without incurring the risks of the "middle ground", alerted by Porter (1991).

Global strategies - regarding product/market - are based on the arguments put forward by Aaker (2001), who says that it is not sufficient to look for strategies providing better organizational performance focused on downsizing, restructuring, redeployment of assets and cost reduction. There is a limit to the increase in profits in efficiency programs. If this limit is not respected it can lead the organization to a situation of reduced gains. The author says that the amount of people and resources that can be eliminated is limited. In this sense, Aaker (2001) suggests that the way to maintain and improve performance has to consider growth.

From the matrix product/market developed by Ansoff (1990), Aaker (2001) presents five growth opportunities for the organization. (1) Growth in existing product/markets - increase market share and/or promote the increased use of the product; (2) Product development for the existing market - add qualities to the product, develop new generation products that can make existing products obsolete, and develop new products for existing markets; (3) Market development using existing products - to expand geographically; enter into new market segments; (4) Diversification is the strategy of developing new products and enter different markets from those with whom the company is currently involved; (5) Vertical integration, which is, as a rule, an unrelated diversification. In vertical integration strategies, the organization can 'swim with the current' regarding the product flow, i.e. move forward in the product chain, as in the case of a manufacturer that buys a retail chain. Also, the organization can choose the opposite direction, 'against the current, such as the case of a manufacturer investing in supply of raw materials.

In Casarotto's (2016) point of view, the three categories of global strategies presented indicate that small businesses have difficulties or major limitations to compete alone. This is because of their slow growth, which could lead them to stay in the "middle ground", or because of the large investments required to push for rapid growth. According to the author, small businesses are left with two options: to become a supplier of a top-down network or join a flexible small business network.

Operational strategies are used by different areas of the business. The value chain shows a division of the business in two sets of activities. The primary activities are the ones involved in the creation of the product, its sale and transfer to the buyer, as well as after-sales service, comprising the processes of: inbound logistics, operations, outbound logistics, marketing and sales, and post-sale services. The other set is comprised of support activities that sustain the primary activities, and include the processes of acquisition of supplies and services, technology development, human resources management and the business infrastructure. The implementation of these 
activities make up the elements that generate competitive advantage for businesses, therefore the value chain is the set of these interdependent activities (Porter, 1990).

\section{Research method}

Part of this work is based on a conceptual and theoretical approach and its purpose is to provide a framework from literature review, analyzing 33 selected articles available from the databases Scopus, Web of Science, Science Direct and Scielo. According to Nakano (2012) the conceptual and theoretical study provides a literature review, develops conceptual models and promotes theoretical discussions. The theoretical study is conducted jointly with the empirical research, characterized by case studies. This research has a qualitative approach whose focus is to explore the elements related to the object in more depth. Taking into account the notes from Voss, Tsikriktsis \& Frohlich (2002) and Eisenhardt (1989), the multiple case study with the aim of broadening/refining a theory that was developed in this study following the proposal of Yin (2010) (Figure 2).

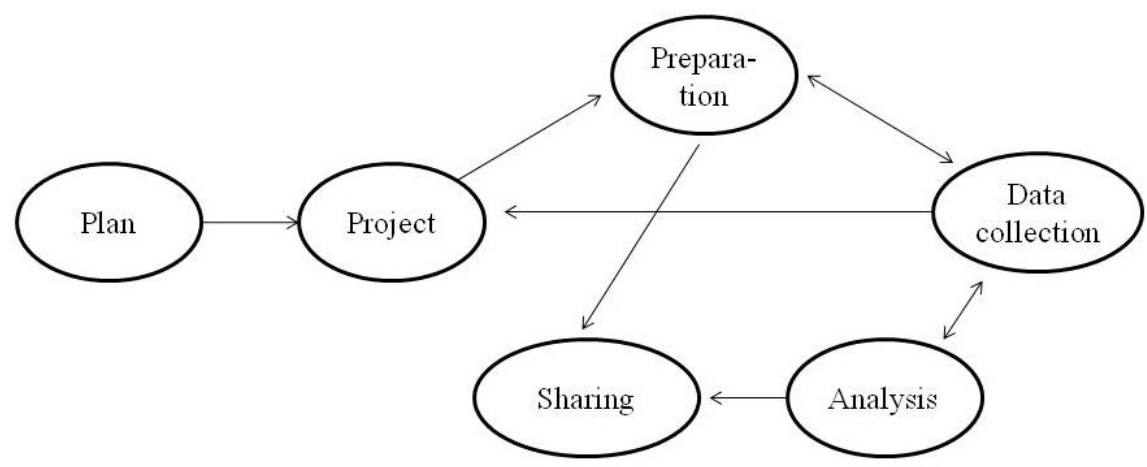

Figure 2. Procedures performed in the case studies performed. Source: Yin (2010, p. 22).

The case study is a method of empirical research that allows researchers to explore contemporary phenomena in depth and in their real-life contexts, such as, among other examples, the organizational processes.

The units of analysis were two networks with horizontal structure and legally established. The first located in Brazil (Ecovida Agro-ecology Network). This study focused on the networks section based at the cost of Santa Catarina, called Núcleo Litoral Catarinense (NLC). It is the country's largest network that promotes participatory certification. The other network researched is based in France and is called Groupement d'Agriculture Biologique. These regional and departmental groups form the largest network of organic production in France. This study took up the regional grouping Agrobio Poitou-Charentes.

For Cauchick Miguel \& Sousa (2012), the number of cases to be studied must be defined in the phase of study design and there are different selection strategies. This study selected two cases referred to by the authors as "revealing" because they represent the leading networks of the countries in the context of organic farming. Analytical generalization (Yin, 2010) of the cases added to the theoretical-conceptual 
study in order to create a theory. The study used mixed methods and conducted a research survey of farmers.

Documents and websites were consulted and observations were made. A total of 18 interviews (800 minutes) and 41 questionnaires in the study of France and 14 interviews (950 minutes) and 43 questionnaires in the Brazilian case. Figure 3 shows the synthesis of methodological procedures.

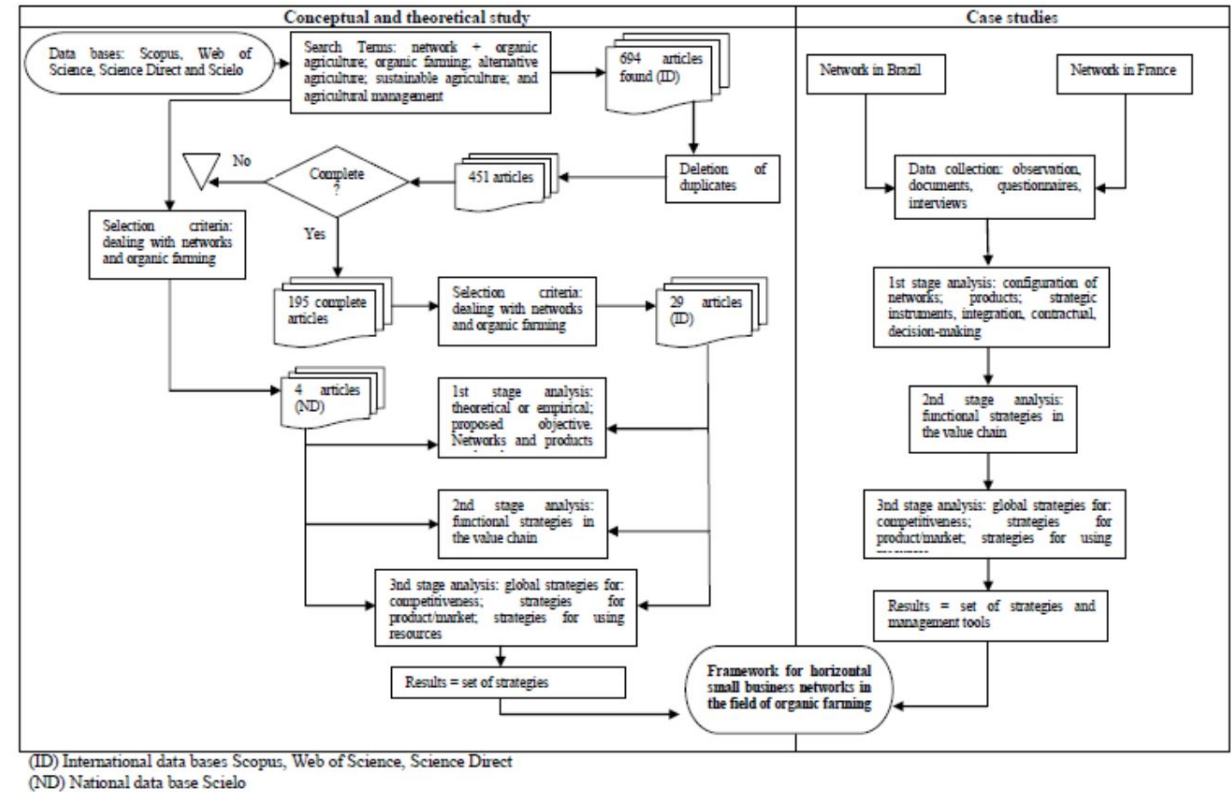

Figure 3. Synthesis of methodological procedures.

\section{Results}

The framework for the management of horizontal networks of small businesses in the field of organic farming (Figure 4) has as its starting point the 33 articles (Table 1) that composed the theoretical data and two case studies conducted in Ecovida NLC and in Agrobio. Data analysis was based on management tools proposed by Balestrin \& Verschoore (2008) and organizational strategy based on the studies of Porter (1990, 1991) Aaker (2001), Casarotto \& Pires (2001) and Casarotto (2016).

Table 1. Articles selected for content analysis - Types and objectives.

\begin{tabular}{ccc} 
References & $\begin{array}{c}\text { Type of } \\
\text { work: } \\
\text { Theoretical } \\
\text { or empiric }\end{array}$ & Objective \\
\hline Blanc (2009) & Empiric & $\begin{array}{l}\text { Verify if family agriculture can benefit from the development } \\
\text { of these "conventional" commercialization circuits in the } \\
\text { organic sector. }\end{array}$ \\
\hline $\begin{array}{c}\text { Chohin-Kuper } \\
\text { \& Kemmoun } \\
(2010)\end{array}$ & Empiric & $\begin{array}{l}\text { To compare the } 10 \text { criteria of fair trade (World Fair Trade } \\
\text { Organization) to the local reality of a group of olive oil } \\
\text { farmers in "Femmes du Rif". }\end{array}$ \\
\hline
\end{tabular}


Table 1. Continued...

\begin{tabular}{|c|c|c|}
\hline References & $\begin{array}{l}\text { Type of } \\
\text { work: } \\
\text { Theoretical } \\
\text { or empiric }\end{array}$ & Objective \\
\hline $\begin{array}{l}\text { Dantsis et al. } \\
\quad(2009)\end{array}$ & Empiric & $\begin{array}{l}\text { Research the interaction of organic farming with the } \\
\text { agro-industry complex. }\end{array}$ \\
\hline $\begin{array}{l}\text { David et al. } \\
\qquad(2010)\end{array}$ & Empiric & $\begin{array}{l}\text { Analyze the strategies and flexibility of organic farms } \\
\text { throughout time in the face of technical, regulatory economic } \\
\text { and social changes challenging agriculture as a whole and } \\
\text { especially organic farming. }\end{array}$ \\
\hline $\begin{array}{l}\text { Demiryurek } \\
\quad(2010)\end{array}$ & Empiric & $\begin{array}{l}\text { Analyze the information systems on agriculture and the } \\
\text { communication networks of organic and traditional hazelnut } \\
\text { farmers in Samsun, Turkey. }\end{array}$ \\
\hline $\begin{array}{l}\text { Finatto \& } \\
\text { Salamoni } \\
(2008)\end{array}$ & Empiric & $\begin{array}{l}\text { Establish a profile of the agro-ecology based production in } \\
\text { the city of Pelotas (Brazil), identifying its general features, } \\
\text { the status of the production and its importance as the city's } \\
\text { family farmers production strategy. }\end{array}$ \\
\hline Fonte (2008) & Empiric & $\begin{array}{l}\text { Study the dynamic of the knowledge as added value in local } \\
\text { gastronomy, based on the results of the Corason project } \\
\text { (cognitive approach for sustainable rural development, the } \\
\text { dynamic of the expert and lay knowledge). }\end{array}$ \\
\hline $\begin{array}{l}\text { Freidberg \& } \\
\text { Goldstein } \\
(2011)\end{array}$ & Empiric & $\begin{array}{l}\text { Describe an attempt to develop an alternative food network. } \\
\text { A box scheme launched by the Kenya Institute of Organic } \\
\text { Farming in } 2007 \text { had the aim of connecting small organic } \\
\text { farmers to consumers in Nairobi. }\end{array}$ \\
\hline $\begin{array}{l}\text { Furman et al. } \\
\qquad(2011)\end{array}$ & Empiric & $\begin{array}{l}\text { Verify how organic farmers in Georgia access and use } \\
\text { services of weather information. }\end{array}$ \\
\hline $\begin{array}{l}\text { Gómez } \\
\text { Tovar et al. } \\
(2005)\end{array}$ & Empiric & $\begin{array}{l}\text { Analyze the two forms of certification used in Mexican } \\
\text { organic farming. }\end{array}$ \\
\hline
\end{tabular}

Holloway et al. Empiric Explore how sustainable agricultural management ideas can (2006) be expressed through broader understanding of network development concerned with local economies and societies, high specialization in quality food products, certain "traditional" agricultural and animal practices, as well as the ecology of a cultivated landscape.

Jarosz (2008) Empiric Identify two place-based processes (urbanization and rural restructuration) that promote as well as limit the rise and development of alternative food networks development.

\begin{tabular}{cll}
$\begin{array}{c}\text { Kohler et al. } \\
(2011)\end{array}$ & Empiric & $\begin{array}{l}\text { Examine the failure of the Association of Alternative Food } \\
\text { Farmers in Ouro Preto do Oeste, in Rondônia (Brazil). }\end{array}$ \\
\hline $\begin{array}{c}\text { Kumbamu } \\
(2009)\end{array}$ & Empiric & $\begin{array}{l}\text { Explore and analyze the organization and operation of the } \\
\text { subaltern peasants sanghams (grassroot association of the } \\
\text { poor) and their strategies in building local and autonomous } \\
\text { communities that challenge the neoliberal globalization } \\
\text { process and the commodification of food and agriculture. In } \\
\text { addition, examines whether autonomous and local-based } \\
\text { communities can survive and thrive in an increasingly } \\
\text { globalized world. }\end{array}$ \\
\hline $\begin{array}{c}\text { Lobley et al. } \\
\text { (2013) }\end{array}$ & Empiric & $\begin{array}{l}\text { Characterize national, regional and local organic food } \\
\text { markets from the supply perspective. Identify local, regional } \\
\text { and national market orientations and consider the } \\
\text { concentration of marketing channels using the Herfindahl- } \\
\text { Hirschman Index. }\end{array}$ \\
\hline Makita (2012) & Empiric & $\begin{array}{l}\text { Research the confluence of fair trade and initiatives of } \\
\text { organic farming based on cotton Bt in India, using as thesis } \\
\text { the conventionalization and a Guthman interpretative }\end{array}$ \\
\hline
\end{tabular}


Table 1. Continued...

\begin{tabular}{|c|c|c|}
\hline References & $\begin{array}{l}\text { Type of } \\
\text { work: } \\
\text { Theoretical } \\
\text { or empiric }\end{array}$ & Objective \\
\hline & & $\begin{array}{l}\text { framework for organic farming in the context of the North of } \\
\text { the country. }\end{array}$ \\
\hline $\begin{array}{l}\text { Marsden \& } \\
\text { Smith (2005) }\end{array}$ & Empiric & $\begin{array}{l}\text { Analyze the importance of specialized food networks for } \\
\text { responding to local/regional crises escalating in agriculture } \\
\text { in the European Union, as well as evaluate whether the } \\
\text { local/regional based networks are able to contribute to } \\
\text { sustainable rural development. }\end{array}$ \\
\hline $\begin{array}{l}\text { Milestad et al. } \\
\quad(2010)\end{array}$ & Empiric & $\begin{array}{l}\text { Explore social relationships among farmers and how the } \\
\text { terms "local" and "organic" are expressed, presenting in } \\
\text { detail how farmers describe the quality of their intra-network } \\
\text { relationship; how they understand the idea of "local"; and } \\
\text { how they are connected within the food system. }\end{array}$ \\
\hline Mount (2012) & Theoretical & $\begin{array}{l}\text { Expand the discussion by questioning the ways in which } \\
\text { scale development can affect the perception and legitimacy } \\
\text { of local food systems and the ability to generate and capture } \\
\text { the added value of local food. }\end{array}$ \\
\hline $\begin{array}{l}\text { Nelson et al. } \\
\quad(2010)\end{array}$ & Empiric & $\begin{array}{l}\text { Research specific limitations in the model of participatory } \\
\text { certification in Mexico and present the case as an example } \\
\text { of how an alternative participatory certification process } \\
\text { emerged in the country. }\end{array}$ \\
\hline $\begin{array}{l}\text { Radomsky \& } \\
\text { Leal (2012) }\end{array}$ & Empiric & $\begin{array}{l}\text { Analyze the international context of the system of intellectual } \\
\text { property over the biodiversity and knowledge production, as } \\
\text { well as study the actions taken by farmers that participate in } \\
\text { the Ecovida Agro-ecology Network in order to create } \\
\text { alternative forms of knowledge management to produce } \\
\text { 'pure' seeds. }\end{array}$ \\
\hline Sage (2003) & Empiric & $\begin{array}{l}\text { Show the importance of mutual respect as a non-economic } \\
\text { dimension of personal relationship among farmers, } \\
\text { consumers and other actors that are part of a good network } \\
\text { of alternative food in Southwest Ireland. }\end{array}$ \\
\hline $\begin{array}{l}\text { Sage \& } \\
\text { Goldberger } \\
(2011)\end{array}$ & Empiric & $\begin{array}{l}\text { To empirically demonstrate the factors that influence } \\
\text { consumer direct stock markets }\end{array}$ \\
\hline $\begin{array}{l}\text { Santos \& } \\
\text { Chalub- } \\
\text { Martins (2012) }\end{array}$ & Empiric & $\begin{array}{l}\text { Analyze and qualify existing "learning" communities within } \\
\text { the framework of the alternative economy. }\end{array}$ \\
\hline $\begin{array}{l}\text { Selfa \& Qazi } \\
\quad(2005)\end{array}$ & Empiric & $\begin{array}{l}\text { Examine two agro-industrial regions in the rural area of } \\
\text { Central Washington. Farmers in those cities have tried to } \\
\text { diversify processing on large scale, focusing on organic } \\
\text { products to niches of the market such as the market of } \\
\text { popular farmers in Seattle. The strategies ask the question: } \\
\text { "how are the local agrifood networks defined socially and } \\
\text { geographically? }\end{array}$ \\
\hline Shreck (2005) & Empiric & $\begin{array}{l}\text { Identify the different forms of social action in which the fair } \\
\text { trade movement is involved and understand where the } \\
\text { movement counter-hegemonic potentials are placed, taking } \\
\text { into consideration the several levels at which fair trade } \\
\text { alternatives operate. }\end{array}$ \\
\hline $\begin{array}{c}\text { Tencati \& } \\
\text { Zsolnai }(2012)\end{array}$ & Theoretical & $\begin{array}{l}\text { Analyze the Slow Food movement and the use of recent } \\
\text { theoretical and empirical contributions in psychology and } \\
\text { behavior science, supporting cooperative business models } \\
\text { as an alternative to current traditional business models. }\end{array}$ \\
\hline $\begin{array}{l}\text { Trauger } \\
(2007)\end{array}$ & Empiric & $\begin{array}{l}\text { Use a cultural-economic approach to comprehend the } \\
\text { strategies adopted by the model of work adopted by a }\end{array}$ \\
\hline
\end{tabular}


Table 1. Continued...

\begin{tabular}{|c|c|c|}
\hline References & $\begin{array}{l}\text { Type of } \\
\text { work: } \\
\text { Theoretical } \\
\text { or empiric }\end{array}$ & Objective \\
\hline & & $\begin{array}{l}\text { cooperative of organic food trade in a rural community in } \\
\text { South-central Pennsylvania. }\end{array}$ \\
\hline $\begin{array}{l}\text { Trauger } \\
(2009)\end{array}$ & Empiric & $\begin{array}{l}\text { Study an 'agency' established by farmers and activists in a } \\
\text { sustainable farming community in Pennsylvania in order to } \\
\text { understand fractions in the system of conventional food and } \\
\text { develop new ways of supplying food in local economies. The } \\
\text { term 'agency' emerged from the collectives and their } \\
\text { relationships according to the Actor-Network Theory. }\end{array}$ \\
\hline Warner (2008) & Empiric & $\begin{array}{l}\text { To defend the idea that agroecology can not be transferred } \\
\text { as technology, but must be extended through participatory } \\
\text { social learning networks. }\end{array}$ \\
\hline $\begin{array}{l}\text { Zahm et al. } \\
\qquad(2008)\end{array}$ & Empiric & $\begin{array}{l}\text { Apply the IDEA (Indicateurs de Durabilité des Exploitations } \\
\text { Agricoles) method, using some adaptations. }\end{array}$ \\
\hline $\begin{array}{c}\text { Zanasi \& } \\
\text { Venturi (2009) }\end{array}$ & Empiric & $\begin{array}{l}\text { Analyze how social cohesion, trust and market mutual } \\
\text { relationship are present throughout the supply chain; } \\
\text { Explain the interaction between the organic farming } \\
\text { participatory certification and the development of rural } \\
\text { communities. }\end{array}$ \\
\hline $\begin{array}{l}\text { Zanoli et al. } \\
\quad(2012)\end{array}$ & Empiric & $\begin{array}{l}\text { Carry out a scenario analysis on the future development of } \\
\text { the organic food market in Europe. }\end{array}$ \\
\hline
\end{tabular}

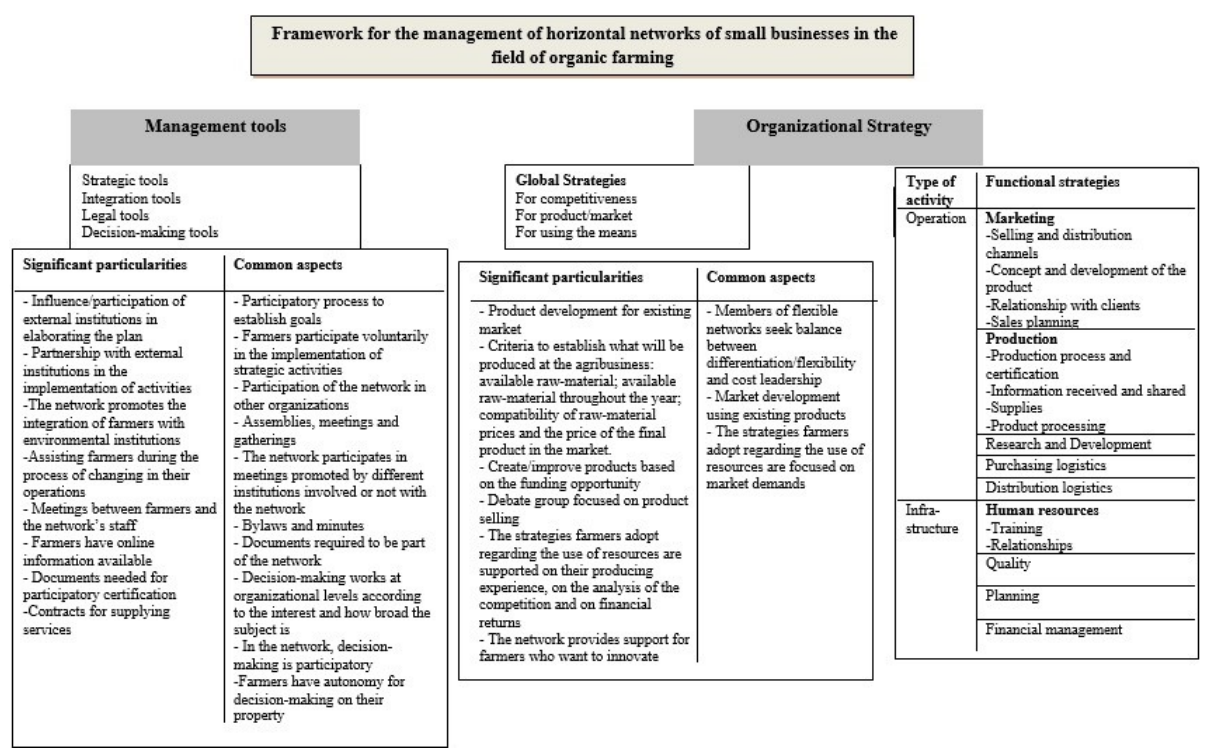

Figure 4. Framework for horizontal small business networks in the field of organic farming.

The construction of Figure 4 was performed in two steps. The first one consisted of the analysis of the articles detailed in Table 1. In this case, global and functional organizational strategies that were presented in the referred articles were extracted. In the second stage, management tools and global and functional organizational strategies of the case studies were extracted. This has resulted in a framework of management tools and organizational strategies found in both articles and case studies. From this result, it was observed that there were common points used by 
several networks, and, on the other hand, peculiarities, often used by one or a few networks, but that presented important results in the performance of the business. Therefore, these elements (instruments and strategies) made up the group of significant particularities in the theoretical-conceptual scheme.

This framework is designed for the network governance and management system (Roth et al., 2012) of small businesses in the field of organic farming, in order to provide tools to develop existing networks as well as providing information in order to help create new networks. To use this framework, the network manager should evaluate the management tools and the proposed strategies in order to select which of these elements the network can use.

In order to build up the framework, relevant aspects were observed regarding significant particularities and common aspects of management tools and organizational strategies.

Figure 4 indicates the relevant aspects related to management tools.

When analyzing the management tools, it is possible to observe that the definition of strategic tools permeates other public and non-governmental organizations. The actions taken involving strategic tools focus on setting goals in a participatory way, but actors such as the federal government and institutions working in agriculture influence the process.

Integration tools consist of meetings between farmers and network staff, as well as participation in meetings involving other actors and institutions external to the network.

Legal tools are designated to regulate the network's internal procedures and to formalize the relationships between actors. Such tools include bylaws, regulations, minutes, contracts, and other documents that formalize the network's operation.

The decision-making tools are connected to participative management. Therefore, the decision-making follows the organizational levels in consonance with the interest and broadness of the subject. In addition, farmers have autonomy to make decisions on their properties.

Relevant aspects were found in the field of organizational strategies. The significant particularities and common aspects are shown in Figure 4.

For the global strategies presented in the framework, it is important to stress the balance between differentiation/flexibility and cost leadership. In global strategies regarding product/market, the theoretical study and the case study of Ecovida NLC pointed to a greater emphasis on market development strategies using existing products. In the case of Agrobio, the emphasis is on both product development strategies for the existing market, and strategies for market development using existing products. Therefore, market development using existing products is the most recurrent product/market strategy. In this type of strategy, diversification of distribution channels is an important activity. Both direct sales at fairs and sales for public or private organizations are used, with emphasis on collective restoration. The market development is also done via wholesale, including exports.

As for the global strategies regarding the use of resources, i.e. the options of investing in new products, maintenance of existing products and the divestments, they are all driven by financial returns, market demand, experience of producing, technical viability of farming in a particular region, research for product innovation and analysis of the competition. For agribusiness, the availability of raw materials throughout the year in addition to prices compatible with the final product offered in the market, are decisive factors in the definition of what will be produced. 
In the identified operational strategies, the ones in marketing, production and human resources were the most frequent respectively.

The operational marketing strategies were the most expressive and covered different fields of action. In the distribution and sales channels, the short sale chain is more often used for vegetables, because when the property produces more variety of food, there is a greater possibility of using direct sales. On the other hand, the long sale chain is used for large cultures and by farmers who produce little variety of crops with a greater amount of each product. The most recurrent forms of sales were on the property, at fairs, small local retailers and public institutions. Among the activities related to the product concept and development, it is worth noting the use of the "designation of origin" for products, and the identification of "local product". The relationship with customers extends from the contact promoted by direct sales, through partnership with retailers to participate in events.

Production process and certification, sub-category of production operational strategies include: technical support for farmers, use of production methods, providing information on how to produce, development of different production practices, participatory certification and certification by auditing. In order to obtain and share information, spaces for discussion are created, such as: communication via e-mail, informal conversations at meetings/network meetings and establishing of specific discussion groups to work on a particular area. Activities related to product processing include processing products in shared or outsourced sites, product traceability, guidance and technical assistance to farmers who wish to carry out projects for the processing of products.

The third most used operational strategy, human resources, includes training and relationships. The training courses are focused on the production and management of rural enterprises. The actions classified as relationship, labor relations take place formally and informally. There is also labor exchange between farmers.

The framework proposed here contributes to the management of horizontal networks, specifically for networks of small producers who work in organic farming. It can work as a guide to management and was built from organizational practices identified in this context.

\section{Conclusion}

The aim of this study was to propose a framework for organizational strategies and management tools for horizontal small business networks in the field of organic farming. The unfolding of research led to the construction of that framework.

The framework for the management of horizontal small business networks in the field of organic farming takes into consideration management tools and organizational strategies, which are relevant and indispensable elements to manage and preserve networks.

When analyzing network management instruments, it is observed that the definition of Agrobio's strategic tools includes public agencies and nonprofits. This is because the French government has goals set for organic production in the country - Ambition Plan Bio - and provides financial resources to facilitate the actions designed to help achieving these goals. In Ecovida this relationship does not happen, and strategic tools are focused on the network's internal matters. Thus, the actions carried out involving strategic tools in both cases focus on setting goals in a participatory way, but are 
influenced by actors such as the federal government and institutions working in the field of agriculture. Farmers voluntarily participate in the implementation of strategic actions.

Integration tools consist of meetings of farmers and network's staff, as well as participation in meetings involving other actors and institutions external to the network. Assemblies, meetings and gatherings are integration tools widely used in addition to the participation of network representatives in meetings held by different institutions involved or not in the network.

Legal tools are designated to regulate the network's internal procedures and to formalize the relationships between actors. Such tools include bylaws, regulations, minutes, contracts, and other documents that formalize the network's operation.

The decision-making tools are applied in a context of participatory management. Therefore, the decision-making follows organizational levels in consonance with the interest and the broadness of the subject. Issues are discussed at meetings of Ecovida network's groups - Groupement d'Agriculture Biologique (GAB) - and, when needed, they are forwarded to an Ecovida network's núcleo - Groupement Régional d'Agriculture Biologique (GRAB). When it is the case, such issues can be discussed in the meeting of Ecovida network's núcleos - Fédération Nationale d'Agriculture Biologique (FNAB). Farmers have autonomy to make decisions on their properties.

The decision-making tools are based on farmers' independence and in participatory decisions, considering the different organizational levels.

As recommended by Demiryurek (2010), strategies adopted individually by network actors were considered as potential strategies for the other actors, as well as for the network management.

In the 'global strategies' presented in the framework, it is important to stress the balance between differentiation/flexibility and cost leadership, in which the farmer participates in flexible business networks. However, differentiation is also used even when the farmer participates in top-down business networks, because organic food as raw materials for agribusiness has restricted supply, and therefore can be considered a differentiated product.

In global strategies regarding product/market, the articles analyzed (theoretical and conceptual study) and the case study of Ecovida NLC pointed to a greater emphasis on market development strategies using existing products. In the case of Agrobio the emphasis is both product development strategies for the existing market, and strategies for market development using existing products. This finding can be explained by the fact that Agrobio has greater development in terms of innovation, as shown in data analysis. Therefore, the market development using existing products is the most recurrent product/market strategy. This may indicate that while in general there is more demand than supply, the networks have not managed to reach all this market.

As for the global strategies regarding the use of resources, they are all driven by financial returns, market demand, experience of producing, technical viability of farming in a particular region, research for product innovation and analysis of the competition. For agribusiness, the availability of raw materials throughout the year in addition to prices compatible with the final product offered in the market, are decisive factors in the definition of what will be produced.

The framework is complete with operational strategies classified according to the activities of the network's value chain. In marketing, activities are aimed at distribution and sales channels, product concept and development, relationship with customers and sales planning. Production strategies include production process and certification, 
as well as obtaining and sharing information, supplies and processing products. As for human resources, the activities are focused on training and relationship building.

Still referring to operational strategies, research and development count on the participation of public institutions. Purchasing and distribution logistic strategies are guided by farmer's individual activities. The quality analysis is done both by farmers and by external agents, such as certification agencies and public institutions. The planning strategies are outlined according to information generated in the properties and arising from external sources, such as public or non governmental agencies operating in the area of sustainability. These organizations provide technical and financial support. Financial strategies were identified as strategies for fundraising, production costs and selling price.

Organizational theories aimed at managing small business networks that cooperate are insufficient and studies of networks as the unit of analysis are still rare. Being part of a network is a strategy adopted by different types of businesses. For the small ones, this strategy is important and can determine their survival in the market; and this can be the case of the networks in the field of organic farming. The small farmer alone is more vulnerable. The network seems to provide them support for solving everyday problems in their business, works to defend the collective interests of the participants, enables sharing of knowledge, and develops in the farmer some social characteristics resulting from the participatory process. In this direction, this study contributes to the governance and management of horizontal networks.

In addition to in natura or processed food products, networks also have cosmetics and cleaning products, raw materials for clothing and construction, crafts, educational activities and rural tourism.

Several authors point out the growth of demand for organic products in the world. This growth can be observed both in Brazil and in France, given the increase in planted area, in the number of farmers, the increase in demand (which still exceeds product supply) and consequently the expansion in sales.

Although Brazil's territory exceeds that of France by more than 15 times, the area devoted to organic farming reveals a disproportionate situation. Organic farming in France corresponds to $1,060,000$ hectares, or $1.6 \%$ of the country's territory (France is $643,801 \mathrm{~km}^{2}$ ). In Brazil, organic farming uses 750,000 hectares, which is only $0.09 \%$ of the country's territory $\left(8,516,000 \mathrm{~km}^{2}\right)$. Because of the growing demand and acreage, it is possible to say that Brazil has a long way to go in the development of organic farming. It is noteworthy that Brazil still has land available to expand production, unlike countries with limited territory like France. Another important factor in Brazil is that organic farming can be implemented in areas of permanent preservation, which are preserved from the expansion of the cities' urban development.

The networks' evolution was researched in the case studies and the results showed that in both networks, in Brazil and in France, the different types of actors showed growth of their activities involving acreage, quantity, variety of products and sales.

France has an institution of public interest, called Agence Bio, formed by the French Ministry of Agriculture and NGOs that make up a national information platform with actions that are part of the dynamic development, the promotion and structuring of French organic farming. This agency monitors actions in the field of organic farming, generating information for the sector. In Brazil, data on organic farming are the responsibility of an institution called MAPA, but the information is still scarce and restricted to the number of farmers and cultivated area. There is no information regarding the market for organic products. 
Regarding characterization, the studied networks have particularities. In Agrobio there is a structured management through regional and departmental groups affiliated to FNAB. In each group there are hired staff, financed by public funds to perform different activities. It is up to the groups to support and encourage organic farming in the region where they operate. In Ecovida network management is voluntary, unpaid and exercised by few people who divide their time between the network management and their activities as farmers. In many cases, the administration of groups is carried out by non-governmental organizations. The network's management do not receive public funds, leaving it to the network members to bear the expenses related to this activity.

Different from France that has only certification by audit, participatory certification is an incentive for the Brazilian organic farmer. The States in the South of Brazil are the ones that more often adopt this kind of certification. This is due to the work of the Ecovida Association of Participatory Certification, which is responsible for the certification of $82.6 \%$ of farmers. In order to obtain the participatory certification, the farmer must be present at several meetings. Certified farmers are often the ones who certify others and visit the properties. As farmers end up having to spend time to prepare documentation relevant to the certification process, leaving behind their core business to mind other tasks, this activity is often understood as a burden. On the other hand, the cost of participatory certification is smaller and the requirements of participation in group and núcleo meetings induce farmers to play a more participatory role and contribute to the network.

In theoretical and empirical studies focused on business networks for organic farming presented here, it was observed that although the networks studied are located in countries on different continents and level of development, there are common features in both.

From the data collected using questionnaires responded by farmers, the authors conducted a comparative analysis between the two networks researched. The analysis showed there are common aspects in both networks, such as gender and age of the respondent, size of property, participation in events promoted by the network, participation in the implementation of network actions, purchasing logistics, distribution logistics, production methods, sharing of production and quality control practices.

Among the partially common aspects, there are the farmers' sources of income. Although their own resources are the most used, the grant from the French government offered to farmers linked to environmental services is a strong incentive for conversion and maintenance of the farmers in organic production, which is different from what happens in Brazil.

Regarding the differences between the elements identified, it was found that the school education of the farmer in France is between high school and a 02-year degree. In Brazil the farmer's average education is between elementary and high school. Processing of food produced on the property is a standard practice in France. Organic products must provide added value beyond the fact that they are organic. That is why product processing is important, either by the farmers themselves or by another member of the network. In the Brazilian case, it still prevails the sale of fresh products with low added value. Brazilian farmers participate more actively in the network, a fact that is possibly embedded in the organizational structure of Ecovida. The network enables the extensive involvement of participants in the activities developed, different to Agrobio, where representatives are elected to take on the management. 
As for the decisions made by farmers regarding the management of their properties, in Brazil the farmers seek guidance from the network's coordination, whereas in France, in most cases, the farmers make decisions themselves individually. Another difference is the products and processes innovation, present more often among French farmers. Finally, Brazilian farmers are more satisfied with the actions of network's coordination than the French farmers are.

As noted before, Ecovida do not have staff, the coordination is made up exclusively of volunteers. This hinders the potential of managers to develop comprehensive and operational strategies, different to Agrobio. This aspect reflects greater wealth in the strategies identified in the Agrobio network.

It is worth noting that the technical support offered to farmers in both networks is directed to groups, i.e., the support activities do not serve farmers individually. This encourages the participation of the farmers in the network as well as the growth of it. The researched networks were created by civil society, from social movements. Taking this into consideration, it is important to reflect on the extent to which establishing artificial network structures, by the government, can effectively engage participants in cooperation, which is voluntary and individual.

The framework proposed here is intended for networks in operation, as well as for new networks and can be a tool for developing cooperation and participation. The management tools and organizational strategies proposed here are elements that can promote participatory management and information sharing.

The limitations of the theoretical and conceptual study and case studies presented here are connected to the choices of the researcher and the object to be studied. Determining which articles will be reviewed and which search terms are most representative of the object to be studied are activities that define what actually makes up the research.

Another limitation is the method of case study, because of the restrictions in using the obtained results for other situations. To reduce this limitation, the research sought the analytical generalization, choosing revealing cases - representative of the studied field - that denote the main networks of their respective countries in the context of organic farming. In addition, the theoretical data presented from the articles allowed to expand the study, bringing elements to build the framework.

Finally, it is possible to indicate future researches with the intention of improving the theoretical-conceptual scheme proposed, in order to broaden the tools for the network management presented here. Likewise, the study can be extended to other nuclei and clusters of the studied networks, as well as to other networks.

\section{Acknowledgements}

This work was funded by the Coordination for the Improvement of Higher Education Personnel (CAPES) - Ministry of Education (Brazil). The research conducted in France counts on the support from Université de Poitiers - Institut d'Administration des Entreprises.

\section{References}

Aaker, D. A. (2001). Administração estratégica de mercado. Porto Alegre: Bookman 
Albers, S. (2010). Configurations of alliance governance systems. Schmalenbach Business Review, 62(3), 204-233. http://dx.doi.org/10.1007/BF03396805.

Andrighi, F. F., Hoffmann, V. E., \& Andrade, M. A. R. (2011). Análise da produção científica no campo de estudo das redes em periódicos nacionais e internacionais. Revista de Administração e Inovação, 8(2), 29-54. http://dx.doi.org/10.5773/rai.v8i2.530.

Ansoff, I. (1990). A nova estratégia empresarial. São Paulo: Atlas.

Arbos, K. A., Freitas, R. J. S., Stertz, S. C., \& Carvalho, L. A. (2010). Segurança alimentar de hortaliças orgânicas: aspectos sanitários e nutricionais. Food Science and Technology, 30(1), 215-220. http://dx.doi.org/10.1590/S0101-20612010000500033.

Balestrin, A., \& Verschoore, J. (2008). Redes de cooperação empresarial: estratégias de gestão na nova economia. Porto Alegre: Bookman.

Blanc, J. (2009). Family farmers and major retail chains in the Brazilian organic sector: assessing new development pathways: a case study in a peri-urban district of São Paulo. Journal of Rural Studies, 25(3), 322-332. http://dx.doi.org/10.1016/j.jrurstud.2009.01.002.

Casarotto, N., Fo., \& Pires, L. H. (2001). Redes de pequenas e médias empresas e desenvolvimento local: estratégias para a conquista da competitividade global com base na experiência italiana. São Paulo: Atlas.

Casarotto, N., Fo. (2016). Elaboração de projetos empresariais: análise estratégica, estudo de viabilidade e plano de negócio (2. ed.). São Paulo: Atlas.

Cauchick Miguel, P. A., \& Sousa, R. (2012).O método do estudo de caso na engenharia de produção. In P. A. Cauchick Miguel (Ed.), Metodologia de pesquisa em engenharia de produção e gestão de operações. Rio de Janeiro: Elsevier, Abepro.

Chohin-Kuper, A., \& Kemmoun, H. (2010). From theory to practice: fair trade in olive oil in Morocco. Cahiers Agricultures, 19(spe1), 17-22.

Dantsis, T., Loumou, A., \& Giourga, C. (2009). Organic agriculture's approach towards sustainability; its relationship with the agro-industrial complex, a case study in Central Macedonia, Greece. Journal of Agricultural \& Environmental Ethics, 22(3), 197-216. http://dx.doi.org/10.1007/s10806-008-9139-0.

David, C., Mundler, P., Demarle, O., \& Ingrand, S. (2010). Long-term strategies and flexibility of organic farmers in southeastern France. International Journal of Agricultural Sustainability, 8(4), 305-318. http://dx.doi.org/10.3763/ijas.2010.0497.

Demiryurek, K. (2010). Analysis of information systems and communication networks for organic and conventional hazelnut producers in the Samsun province of Turkey. Agricultural Systems, 103(7), 444-452. http://dx.doi.org/10.1016/j.agsy.2010.04.002.

Eisenhardt, K. (1989). Building theories from case study research. Academy of Management Review, 14(4), 532-550. http://dx.doi.org/10.5465/amr.1989.4308385.

Finatto, R. A. S. G., \& Salamoni, G. (2008). Agricultura familiar e agroecologia: perfil da produção de base. Sociedade \& Natureza, 20(2), 199-217. http://dx.doi.org/10.1590/S1982-45132008000200012.

Fleury, A. (2012). Planejamento do projeto de pesquisa e definição do modelo teórico. In P. A. Cauchick Miguel (Ed.), Metodologia de pesquisa em engenharia de produção e gestão de operações. Rio de Janeiro: Elsevier, Abepro.

Fonte, M. (2008). Knowledge, food and place: a way of producing, a way of knowing. Sociologia Ruralis, 48(3), 200-222. http://dx.doi.org/10.1111/j.1467-9523.2008.00462.x.

Freidberg, S., \& Goldstein, L. (2011). Alternative food in the global south: reflections on a direct marketing initiative in Kenya. Journal of Rural Studies, 27(1), 24-34. http://dx.doi.org/10.1016/j.jurstud.2010.07.003.

Furman, C., Roncoli, C., Crane, T., \& Hoogenboom, G. (2011). Beyond the "fit": introducing climate forecasts among organic farmers in Georgia (United States). Climatic Change, 109(3-4), 791-799. http://dx.doi.org/10.1007/s10584-011-0238-y. 
Gómez Tovar, L., Martin, L., Gómez Cruz, M. A., \& Mutersbaugh, T. (2005). Certified organic agriculture in Mexico: market connections and certification practices in large and small producers. Journal of Rural Studies, 21(4), 461-474.

http://dx.doi.org/10.1016/j.jurstud.2005.10.002.

Holloway, L., Cox, R., Venn, L., Kneafsey, M., Dowler, E., \& Tuomainen, H. (2006). Managing sustainable farmed landscape through 'alternative' food networks: a case study from Italy. The Geographical Journal, 172(3), 219-229. http://dx.doi.org/10.1111/j.14754959.2006.00205.x.

International Federation of Organic Agriculture Movements - IFOAM. (2017). Annual report 2017. Retrieved in 2014, May 1, from https://ifoam.bio/en/our-library/annual-reports

Jarosz, L. (2008). The city in the country: growing alternative food networks in metropolitan areas. Journal of Rural Studies, 24(3), 231-244. http://dx.doi.org/10.1016/j.jurstud.2007.10.002.

Kim, W. C., \& Mauborgne, R. (2005). A estratégia do oceano azul: como criar novos mercados e tornar a concorrência irrelevante. Rio de Janeiro: Elsevier.

Kohler, F., Issberner, L. R., Léna, P., \& Marchand, G. (2011). Falência é fracasso? O caso da Associação dos Produtores Alternativos de Ouro Preto do Oeste, Rondônia, Brasil. Boletim do Museu Paraense Emílio Goeldi. Ciências Humanas, 6(2), 319-331. http://dx.doi.org/10.1590/S1981-81222011000200005.

Kumbamu, A. (2009). Subaltern strategies and autonomous community building: a critical analysis of the network organization of sustainable agriculture initiatives in Andhra Pradesh. Community Development Journal: an International Forum, 44(3), 336-350. http://dx.doi.org/10.1093/cdj/bsp024.

Lastres, H. M. M., \& Cassiolato, J. E. (2003). Glossário de arranjos e sistemas produtivos e inovativos locais. Retrieved in 2014, May 1, from http://www.cronologia.desenvolvimento.gov.br/arquivos/dwnl_1289323549.pdf

Lobley, M., Butler, A., \& Reed, M. (2009). The contribution of organic farming to rural development: an exploration of the socio-economic linkages of organic and non-organic farms in England. Land Use Policy, 26(3), 723-735. http://dx.doi.org/10.1016/j.landusepol.2008.09.007.

Lobley, M., Butler, A., \& Winter, M. (2013). Local organic food for local people? organic marketing strategies in england and wales. Regional Studies, 47(2), 216-228. http://dx.doi.org/10.1080/00343404.2010.546780.

Louden, F. N., \& Macrae, R. J. (2010). Federal regulation of local and sustainable food claims in Canada: a case study of Local Food Plus. Agriculture and Human Values, 27(2), 177-188. http://dx.doi.org/10.1007/s10460-009-9209-6.

Makita, R. (2012). Fair Trade and organic initiatives confronted with Bt cotton in Andhra Pradesh, India: a paradox. Geoforum, 43(6), 1232-1241. http://dx.doi.org/10.1016/j.geoforum.2012.03.009.

Marcon, C., \& Moinet, T. N. (2001). Estratégia-rede. Caxias do Sul: Educs.

Marsden, T., \& Smith, E. (2005). Ecological entrepreneurship: sustainable development in local communities through quality food production and local branding. Geoforum, 36(4), 440451. http://dx.doi.org/10.1016/j.geoforum.2004.07.008.

Maxey, L. (2006). Can we sustain sustainable agriculture? Learning from small-scale producersuppliers in Canada and the UK. The Geographical Journal, 172(3), 230-244. http://dx.doi.org/10.1111/j.1475-4959.2006.00211.x.

Milestad, R., Bartel-Kratochvil, R., Leitner, H., \& Axmann, P. (2010). Being close: the quality of social relationships in a local organic cereal and bread network in Lower Austria. Journal of Rural Studies, 26(3), 228-240. http://dx.doi.org/10.1016/j.jrurstud.2010.01.004. 
Mintzberg, H. (2001). Os 5 Ps da estratégia. In H. Mintzberg \& J. B. Quinn (Eds.), O processo da estratégia. Porto Alegre: Bookman.

Mount, P. (2012). Growing local food: scale and local food systems governance. Agriculture and Human Values, 29(1), 107-121. http://dx.doi.org/10.1007/s10460-011-9331-0.

Nakano, D. (2012). Métodos de pesquisa adotados na engenharia de produção e gestão de operações. In P. A. Cauchick Miguel (Ed.), Metodologia de pesquisa em engenharia de produção e gestão de operações. Rio de Janeiro: Elsevier, Abepro.

Nelson, E., Gómez Tovar, L., Rindermann, R. S., \& Gómez Cruz, M. A. (2010). Participatory organic certification in Mexico: an alternative approach to maintaining the integrity of the organic label. Agriculture and Human Values, 27(2), 227-237.

http://dx.doi.org/10.1007/s10460-009-9205-x.

Porter, M. E. (1990). Vantagem competitiva: criando e sustentando um desempenho superior. Rio de Janeiro: Campus.

Porter, M. E. (1991). Estratégia competitiva: técnicas para análise de indústrias e da concorrência. Rio de Janeiro: Campus.

Raab, J., \& Kenis, P. (2009). Heading toward a society of networks: empirical developments and theoretical challenges. Journal of Management Inquiry, 18(3), 198-210. http://dx.doi.org/10.1177/1056492609337493.

Radomsky, F. W., \& Leal, O. F. (2012). From the production of rules to seed production: Global Intellectual Property and local knowledge. Vibrant Virtual Brazilian Anthropology, 9(1), 451472. http://dx.doi.org/10.1590/S1809-43412012000100015.

Retamales, J. B. (2011). World temperate fruit production: characteristics and challenges. Revista Brasileira de Fruticultura, 33(1), 121-130. http://dx.doi.org/10.1590/S010029452011000500015.

Ricciardi, A. (2012). I distretti tra crisi e ripresa: i resultati del III Rapporto (2011) dell'Osservatorio Nazionale Distretti Italiani. In F. Mosconi (Ed.), La metamorfosi del "modelo emiliano". Bologna: II Molino.

Roth, A. L., Wegner, D., Antunes, J. A. V., Jr., \& Padula, A. D. (2012). Diferenças e interrelações dos conceitos de governança e gestão de redes horizontais de empresas: contribuições para o campo de estudos. Revista ADM, 47(1), 112-123. http://dx.doi.org/10.5700/rausp1029.

Sacomano, M., No., \& Paulillo, L. F. O. (2012). Estruturas de governança em arranjos produtivos locais: um estudo comparativo nos arranjos calçadistas e sucroalcooleiro no estado de São Paulo. Revista de Administração Pública, 46(4), 1131-1156. http://dx.doi.org/10.1590/S0034-76122012000400011.

Sage, C. (2003). Social embeddedness and relations of regard: alternative 'good food' networks in south-west Ireland. Journal of Rural Studies, 19(1), 47-60. http://dx.doi.org/10.1016/S0743-0167(02)00044-X.

Sage, J. L., \& Goldberger, J. R. (2011). Decisions to direct market: geographic influences on conventions in organic production. Applied Geography, 34(1), 57-65. http://dx.doi.org/10.1016/j.apgeog.2011.10.014.

Santos, F. P., \& Chalub-Martins, L. (2012). Agroecologia, consumo sustentável e aprendizado coletivo no Brasil. Educação e Pesquisa, 38(2), 469-484. http://dx.doi.org/10.1590/S151797022011005000008.

Selfa, T., \& Qazi, J. (2005). Place, taste, or face-to-face? Understanding producer-consumer networks in "local" food systems in Washington State. Agriculture and Human Values, 22(4), 451-464. http://dx.doi.org/10.1007/s10460-005-3401-0.

Shreck, A. (2005). Resistance, redistribution, and power in the Fair Trade banana initiative. Agriculture and Human Values, 22(1), 17-29. http://dx.doi.org/10.1007/s10460-004-7227-y. 
Tencati, A., \& Zsolnai, L. (2012). Collaborative enterprise and sustainability: the case of Slow Food. Journal of Business Ethics, 110(3), 345-354. http://dx.doi.org/10.1007/s10551-0111178-1.

Trauger, A. (2009). Social agency and networked spatial relations in sustainable agriculture. Area, 41(2), 117-128. http://dx.doi.org/10.1111/j.1475-4762.2008.00866.x.

Trauger, A. (2007). Un/re-constructing the agrarian dream: going back-to-the-land with an organic marketing co-operative in south-central Pennsylvania, USA. Tijdschrift voor Economische en Sociale Geografie, 98(1), 9-20. http://dx.doi.org/10.1111/j.14679663.2007.00372.x.

Voss, C., Tsikriktsis, N., \& Frohlich, M. (2002). Case research in Operations Management. International Journal of Operations \& Production Management, 22(2), 195-219. http://dx.doi.org/10.1108/01443570210414329.

Warner, K. D. (2008). Agroecology as participatory science emerging alternatives to technology transfer extension practice. Science, Technology \& Human Values, 33(6), 754-777. http://dx.doi.org/10.1177/0162243907309851.

Wegner, D., \& Padula, A. D. (2011). Estratégias de crescimento e a governança de redes horizontais de empresas: o caso da maior rede cooperativa de varejo de alimentos na Alemanha. Revista de Ciências da Administração, 13(30), 220-248. Retrieved in 2018, March 26, from http://www.redalyc.org/html/2735/273520054010/

Yin, R. K. (2010). Estudo de caso: planejamento e métodos. Porto Alegre: Bookman.

Zahm, F., Viaux, P., Vilain, L., Girardin, P., \& Mouchet, C. (2008). Assessing Farm Sustainability with the IDEA Method: from the concept of agriculture sustainability to case studies on farms. Sustainable Development, 16(4), 271-281. http://dx.doi.org/10.1002/sd.380.

Zanasi, C., \& Venturi, P. S. M. R. C. (2009). Participative organic certification, trust and local rural communities development: the case of Rede Ecovida. New Medit, 8(2), 56-64.

Retrieved in 2008, September 22, from http://www.iamb.it/share/img_new_medit_articoli/257_56zanasi.pdf

Zanoli, R., Gambelli, D., \& Vairo, D. (2012). Scenarios of the organic food market in Europe. Food Policy, 37(1), 41-57. http://dx.doi.org/10.1016/j.foodpol.2011.10.003. 